\title{
The Relationship Between the Expression of the Epithelial Blood-group Substances and Malignancy: A Preliminary Report
}

DONALD I. GEORGE, JR., CARL T. HANKS, RICHARD M. COURTNEY, and DENNIS E. LOPATIN

Departments of Oral Pathology and Immunology, University of Michigan School of Dentistry, Ann Arbor, Michigan 48109

J Dent Res 59(5):831, May 1980

Neoplastic oral squamous epithelial cells have been demonstrated by this author (Oral Surg, $47: 51-57,1979$ ) as well as others (Prendergast, R.C., J Dent Res, 47:306-310, 1968) to be nonreactive to antisera directed against the bloodgroup substances. Non-malignant cells do have this reactivity located on their cell surface membrane (Brandtzaeg, P., Acta Odontol Scand, 23: $335-345,1965)$. Previous investigators have concluded that malignant cells do not contain the blood-group carbohydrates as constituents of their glycocalyces. However, work conducted by Kassulke ( $J$ Natl Cancer Inst, 46:1201, 1971), as well as others with malignant lymphoid cells, concluded that such sugars as the blood-group substances are "masked" beneath a surface covering of the 9 carbon sugar, sialic acid.

It was therefore the intent of this investigation to attempt to determine whether the blood-group substances on oral squamous carcinoma cells are not produced or are simply masked on the cell surface.

The enzy me neuraminidase was used to attempt to remove any surface coating of sialic acid. The technique used was modified from that of Simmons and Rios (Science, 174:591-593, 1971). Frozen sections of oral squamous mucosa, both normal and malignant, were treated with enzyme concentrations of $25 \mathrm{U} / \mathrm{ml}, 100 \mathrm{U} / \mathrm{ml}$, and $250 \mathrm{U} / \mathrm{ml}$ for one hour, $37^{\circ} \mathrm{C}$, at $\mathrm{pH} 5.5$. (One $U$ of Vibrio cholerae neuraminidase activity is defined by the manufacturer as being equivalent to the release of $1 \mu \mathrm{g}$ of sialic acid for a glycoprotein substrate at $37^{\circ} \mathrm{C}$ in 15 minutes at $\mathrm{pH}$ 5.5.)

In order to test for the presence or absence of sialic acid on the cell surfaces, the fluorosceinisothiocyanate-labeled lectin Limulus Polyhemus Agglutinin was used. This lectin is defined by the manufacturer ${ }^{+}$to be specially reactive against sialic acid.

When viewed under the fluorescent microscope, no sialic acid fluorescence was observed in either the normal or malignant tissues.

In order to test the second hypothesis, that the blood-group substances are not produced by neoplastic epithelial cells, isothiocyanate-labeled lectins were used which are specifically crossreactive against the component sugars of the

Received for publication April 16, 1979

Accepted for publication May 4, 1979

${ }^{+} \mathrm{E}-\mathrm{Y}$ Laboratories, San Mateo, CA "backbone" macromolecule of the complete bloodgroup carbohydrate. These lectins were Lotus Tetragonobolus, specific for the sugar residue Lfucose, Triticum Vulgaris Agglutinin, specific for N-acetyl-B-(1-4)-D-glucosamine, and Arachis Hypogaea Agglutinin, specific for D-gal-B-(1-3)$\mathrm{N}$-acetylgalactosamine. From the figure it can be seen that these sugars are combined in the specific order from the serine amino acid attachment of GALNAC to GAL, GNAC, GAL, GNAC, GAL, with $L$-fucose residues attached near the terminal ends.

Results determined by the immunofluorescent preliminary investigation reveal that the most reactive sugar residue found on the cell membranes of malignant epithelial cells is N-acetyl-B-(1-4)D-glucosamine. There was slight fluorescence after treatment of the cells with Arachis Hypogaea, specific for D-gal-B-(1-3)-N-acetylgalactosamine. No reactivity was found for the $L$-fucose residues.

From these preliminary results it seems possible that the blood-group macromolecular structure is terminated at the level of N-acetyl-B-(1-4)-Dglucosamine in most instances. Some cells also appear to terminate the substance at D-gal-B(1-3)- $\mathrm{N}$-acetylgalactosamine. It is interesting to correlate these findings with those of Podosky, Weiser, and Isselbacher (New Engl J Med, 299(13): 703-705, 1978). They state that they have discovered an increase in a mutant galactose transferring enzyme, galactosyl-transferase isoenzyme II, in patients with cancer. It appears from our preliminary results that it is precisely at the level of galactose that the blood-group substances are terminated in malignant cells. Further work is now being conducted in our laboratory to test this hy pothesis.

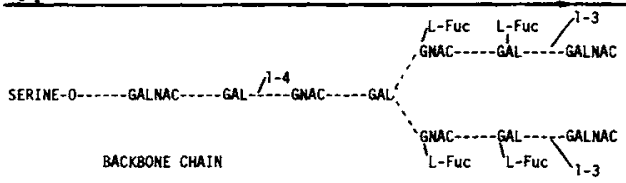

GROUP SPECIFICITY

Blood-group macromolecule for type $A$

$$
\begin{aligned}
& \text { GALNAC D-ga\}-B-(1-3)-N-acetylgalactosanine } \\
& \text { GAL galactose } \\
& \text { GKAC N-acetyl-B-(I-4)-D-glucosantne } \\
& \text { L-Fuc L-fucose }
\end{aligned}
$$

Figure 